\title{
Vicarious liability in Australia: On the move?
}

\author{
JAMES GOUDKAMP AND JAMES PLUNKETT* \\ University of Oxford
}

The recent decision of the High Court of Australia in Prince Alfred College v ADC is a landmark case in the law of vicarious liability. It is the first time in almost 14 years that the High Court has grappled in earnest with the second stage of the test for vicarious liability. This note observes that Prince Alfred College charts a far more restrictive course for the vicarious liability doctrine than has been followed by UK courts. It examines the different trajectories of the law in Australia and the UK and explores possible reasons for this difference.

Keywords: Vicarious liability; tort law; battery; sexual abuse; scope of employment.

\section{Introduction}

The Supreme Court of the United Kingdom has relentlessly expanded the circumstances in which vicarious liability arises. In early 2017, the Court heard the appeal in Armes $v$ Nottinghamshire County Council, ${ }^{1}$ in which a further extension is being sought. This expansion is encapsulated by Lord Phillips PSC's oft-cited remark in Various Claimants $v$ Catholic Child Welfare Society that the law in this area 'is on the move'. ${ }^{2}$ In Cox v Ministry of Justice Lord Reed JSC noted that 'it has not yet come to a stop' 3

The experience in the UK in this regard contrasts sharply with that in Australia, where the operation of the doctrine of vicarious liability is significantly more limited. In Prince Alfred College Inc v ADC, ${ }^{4}$ the High Court of Australia authoritatively restated the law on vicarious liability and in doing so confirmed that significant differences exist between the law in Australia and the UK in this area. The decision merits analysis in this forum for two main reasons. The first is that UK courts have long paid close attention to Australian authorities on vicarious liability. ${ }^{5}$ Prince Alfred College is, therefore, likely to receive close scrutiny in this jurisdiction. The second is that it is rewarding to reflect upon the differences in the law of

james.goudkamp@law.ox.ac.uk

[2015] EWCA Civ 1139. The Court of Appeal's decision is noted in Phillip Morgan, 'Fostering, Vicarious Liability, Non-Delegable Duties, and Intentional Torts' (2016) 132 Law Quarterly Review 399.

2 [2012] UKSC 56 [19].

3 [2016] UKSC $10[1]$.

4 [2016] HCA 37.

5 Australian law is discussed in eg Lister v Hesley Hall Ltd [2001] UKHL 22 [81]; Dubai Aluminium Co Ltd v Salaam [2002] UKHL 48 [32]; Mohamud v Wm Morrison Supermarkets plc [2016] UKSC 11 [29]. 
vicarious liability between Australia and the UK and to consider the reasons for those differences.

\section{The expansion of vicarious liability in English law}

In order to set the scene for the analysis that follows, we begin by delineating the key features of the English law on vicarious liability. Consistently with the paradigm of personal responsibility, the law of torts generally imposes liability on a defendant only if the defendant personally breached an obligation that was owed to the claimant. Vicarious liability is the common law's 'one true exception' to this position. ${ }^{6}$ It arises where (1) the defendant stood in the requisite relationship with the tortfeasor at the relevant time and (2) the tortfeasor's wrong is associated in the necessary way with that relationship.

Various types of relationship are capable of satisfying the first stage of this test, although employment is the paradigmatic relationship. The demands made by the first stage have been progressively relaxed. In Viasystems (Tyneside) Ltd v Thermal Transfer (Northern) $L t d$, so-called 'dual vicarious liability' was recognised. ${ }^{7}$ Dual vicarious liability involves more than one person-usually a permanent and temporary employer-being held vicariously liable for an employee's tort. The landmark decision of the Supreme Court in Various Claimants further and significantly weakened the stringency of the first stage. ${ }^{8}$ In that case, the Court held that a relationship that is 'akin to employment' is sufficient. This 'stretching of the law' (to borrow Patrick Atiyah's graphic phrase ${ }^{9}$ ) continued in Cox, in which the Ministry of Justice was held vicariously liable for the negligence of a prisoner who, in the course of carrying out duties in the prison's kitchen, injured the prison's catering manager. ${ }^{10}$ Lord Reed JSC ${ }^{11}$ said that a relationship other than one of employment may attract vicarious liability

where harm is wrongfully done by an individual who carries on activities as an integral part of the business activities carried on by a defendant and for its benefit ... and where the

\footnotetext{
$6 \quad$ Woodland v Swimming Teachers Association [2013] UKSC 66 [3] (Lord Sumption JSC).

7 [2005] EWCA Civ 1151 esp at [49].

$8 \quad$ Various Claimants (n 2).

$9 \quad$ PS Atiyah, The Damages Lottery (Hart 1997) chs 2-3.

$10 \operatorname{Cox}(\mathrm{n} 3)$.

11 Lord Neuberger PSC, Lady Hale DPSC, Lord Dyson and Lord Toulson JJSC concurring.
} 
commission of the wrongful act is a risk created by the defendant by assigning those activities to the individual in question. ${ }^{12}$

Lord Reed emphasised that by 'business activities' he did not mean to refer only to 'activities of a commercial nature'. ${ }^{13}$

The second stage of the test asks whether there was a 'close connection' between 'the act of the employee and the duties he is engaged to perform broadly defined'. ${ }^{14}$ In applying the second stage of the test, the court enquires as to whether 'it would be fair and just to hold the [defendant] vicariously liable'. ${ }^{15}$ Traditionally, the relationship must afford more than 'the mere opportunity' to commit a tort. ${ }^{16}$ However, this requirement has been interpreted 'liberally' ${ }^{17}$ This is exemplified by the recent decision of the Supreme Court in Mohamud v Wm Morrison Supermarkets plc. ${ }^{18}$ In that case, an employee of a petrol station violently attacked a customer who had, after checking the pressure of the tyres on his car, asked whether it was possible for him to print some documents using the petrol station's printer. The Court held that the second stage of the test was satisfied. Lord Toulson JSC ${ }^{19}$ said that the assault was a 'seamless episode' and that, by telling the customer never to return to the petrol station, the employee was acting "within the "field of activities" assigned to him'. ${ }^{20}$ Phillip Morgan persuasively contends that 'Mohamud appears to [leave] little ... of the "mere opportunity" qualification'. ${ }^{21}$ Indeed, in our view, the result of Mohamud is that the qualification has been essentially emasculated. ibid [30]. Lister (n 5) [80]. The 'close connection' test has been repeatedly affirmed and applied: see eg Mohamud (n 5) [46].

Lister (n 5) [28] (Lord Steyn). See also Lord Toulson JSC in Mohamud (n 5) [45], who determined the closeness of the connection by asking whether it was 'right' for the employer to be held vicariously liable.

16 eg Lister (n 5) [45] (Lord Clyde).

17 Phillip Morgan, 'Ripe for Reconsideration: Foster Carers, Context, and Vicarious Liability' (2012) 20 Torts Law Journal 110, 114.

18 Mohamud (n 5).

19 Lord Neuberger PSC, Lady Hale DPSC, Lord Dyson and Lord Reed JJSC concurring.

20 Mohamud (n 5) [47].

21 Phillip Morgan, 'Certainty in Vicarious Liability: A Quest for a Chimaera?' (2016) 75 Cambridge Law Journal 202, 205. 


\section{Prince Alfred College}

The claimant in Prince Alfred College was a student at the defendant's boarding school. In 1962 , one of the school's housemasters repeatedly abused the then 12-year-old claimant. The abuse took place in the claimant's bedroom after 'lights out'. In 2007, the housemaster was convicted of indecent assault in respect of this abuse. In 2008, the claimant commenced proceedings against the school. He alleged that the school had breached both its ordinary duty of care in negligence as well as its non-delegable duty. The claimant also asserted that the school was vicariously liable for the housemaster's torts. The claimant failed on all three grounds at first instance (as well as on account of a limitation bar). ${ }^{22}$ On appeal to the Full Court of the Supreme Court of South Australia, the claimant succeeded on the vicarious liability issue. ${ }^{23}$ The school in turn appealed to the High Court, with the principal question being whether stage two of the test for vicarious liability was satisfied.

French CJ, Kiefel, Bell, Keane and Nettle JJ, who gave joint reasons, ${ }^{24}$ began by recognising that the previously leading Australian case on the second stage, New South Wales $\mathrm{v}$ Lepore ${ }^{25}$ had failed to establish a clear approach. The law was said to be 'uncertain'. ${ }^{26}$ (Lord Phillips PSC had put things rather more robustly in Various Claimants, remarking that Lepore offered a 'bewildering variety of analysis'. ${ }^{27}$ ) The joint reasons criticised tests that were phrased in terms of 'connections'. ${ }^{28}$ They similarly condemned approaches that depended on what was 'fair and just' on the basis that they reduce the law to a mere 'value judgment ${ }^{29}$ and leave it unclear. ${ }^{30}$

It was against this background that the joint reasons re-expressed the law. The approach that was endorsed was based on the idea of providing the 'occasion' rather than a mere

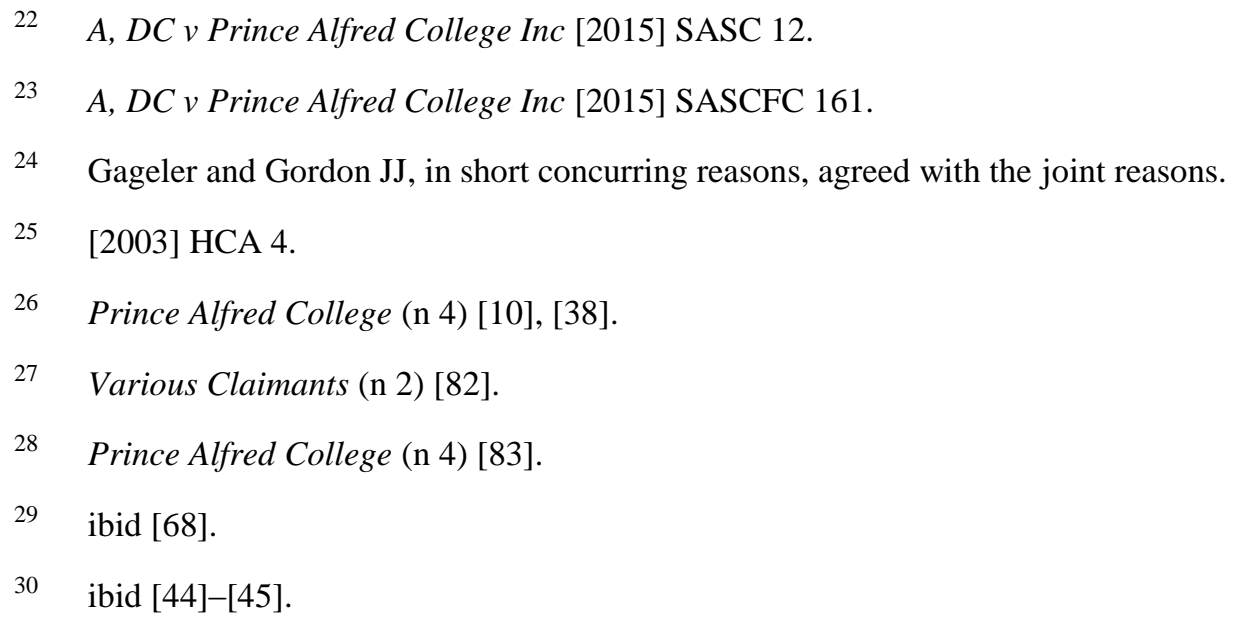


'opportunity' for the commission of the wrong. ${ }^{31}$ The following passage is central to the analysis:

The relevant approach is to consider any special role that the employer has assigned to the employee and the position in which the employee is thereby placed vis-à-vis the victim. In determining whether the apparent performance of such a role may be said to give the "occasion" for the wrongful act, particular features may be taken into account. They include authority, power, trust, control and the ability to achieve intimacy with the victim. The latter feature may be especially important. Where, in such circumstances, the employee takes advantage of his or her position with respect to the victim, that may suffice to determine that the wrongful act should be regarded as committed in the course or scope of employment and as such render the employer vicariously liable. ${ }^{32}$

The joint reasons emphasised that such a test could encompass intentional criminal behaviour, ${ }^{33}$ noting that the facts of Lister, which involved the sexual abuse of pupils by a boarding house warden, would satisfy the test, but those in Mohamud would not. ${ }^{34}$ This was said to be so because the wrongdoer in Lister was in 'a position of power, authority and control vis-à-vis the victim' while the wrongdoer in Mohamud was not. ${ }^{35}$

On the facts of Prince Alfred College, the joint reasons held that, due to the length of time that had elapsed since the abuse, it was inappropriate to determine whether the second stage of the test for vicarious liability was satisfied. ${ }^{36}$ The claim consequently failed.

\section{Analysis}

Prince Alfred College is the first decision on vicarious liability at the ultimate appellate level in Australia in almost 14 years. It is timely in light of the ongoing Australian Royal Commission into Institutional Responses to Child Sex Abuse, which will likely unearth historic instances of abuse and lead to more such cases coming before the courts. ${ }^{37}$ Perhaps the principal significance of Prince Alfred College is that, by making it clear that the facts of Mohamud would not satisfy Australia's new 'occasion'-based test, the High Court has

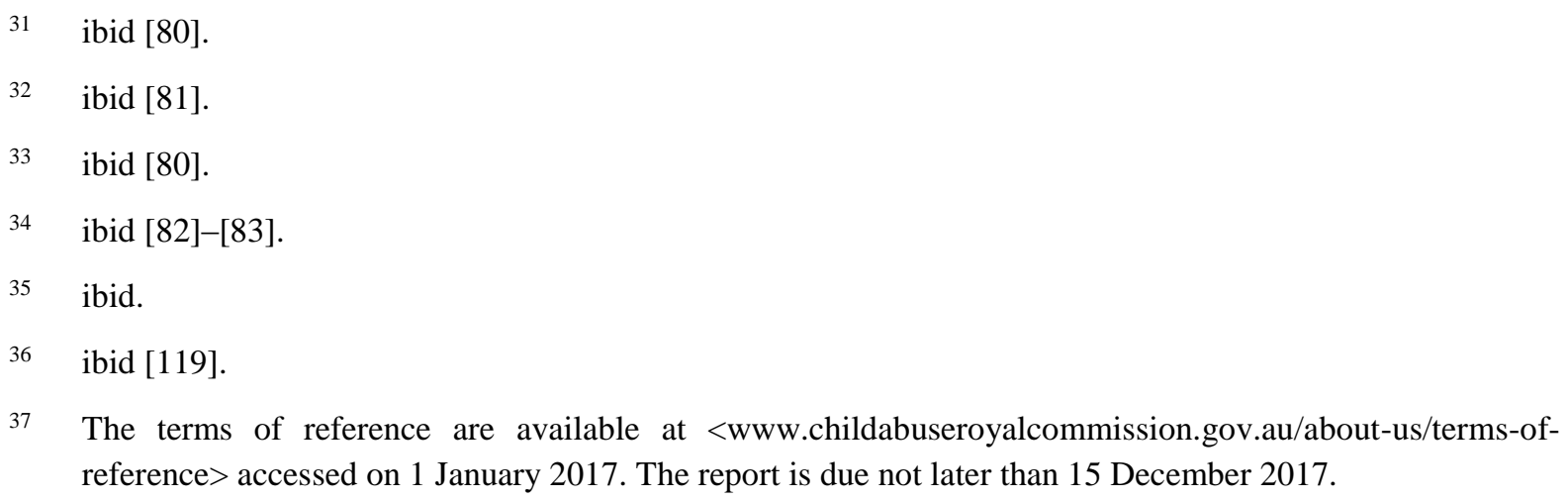


explicitly endorsed a more restrictive approach to the second stage of the vicarious liability test than has been taken in the UK. Beyond this general observation, we have six points to make about Prince Alfred College.

First, it is unclear what the judgment's implications are for the first stage of the test for vicarious liability, the High Court having concentrated on the second stage. On the one hand, Prince Alfred College may be interpreted as approving a conservative approach to vicarious liability in general. In that event, the prospects of Australian courts following the lead of the UK Supreme Court in expanding the first stage of the test are slim. On the other hand, the relatively strict approach to the second stage of the test may ultimately encourage a more liberal approach to the first stage on the basis that Prince Alfred College provides a check at the second stage on what would otherwise be an overly expansive vicarious liability doctrine. Put differently, Prince Alfred College means that there is less danger that a wide approach at stage one will lead to overly expansive liability with the result that a more expansive interpretation of stage one might be encouraged. Lord Reed JSC recently observed in Cox that the two stages of the test for vicarious liability are 'inter-connected'. ${ }^{38}$ As the foregoing shows, the precise nature of the inter-connection has not yet been determined.

Our second point concerns the fact that the High Court in Prince Alfred College drew a distinction between an 'occasion' for the wrongful act (which is capable of satisfying the second stage of the test for vicarious liability) and a mere 'opportunity' (which is incapable of doing so). It is not immediately clear to us in what this distinction consists. Although the joint reasons stressed that it is necessary to consider in this connection the wrongdoer's 'authority, power, trust, control and the ability to achieve intimacy' with the victim, ultimately, the joint reasons' attempt to cleave a distinction between an occasion and an opportunity is unsatisfying. The analysis seems overly focused on terminology. We suspect that the labels employed are essentially devoid of content with the result that it will be difficult to divine when a set of facts reaches the threshold of an 'occasion' for the wrongful act.

Our third point is that although the second stage of the test for vicarious liability is supposedly focused on the connection between the tort and the wrongdoer's relationship with 
the defendant, the approach of the High Court may be best understood as focussing on the closeness of the connection between the tort and the wrongdoer's relationship with the victim. This distinction is subtle but nevertheless significant. It appears to offer a better explanation of the way in which the High Court thought that the leading cases should be decided. For example, in Lister (the outcome of which the High Court approved) the school was held vicariously liable for sexual abuse of pupils committed by its warden because the warden had been entrusted with the pupils' protection. The position in Mohamud (the result in which the High Court disapproved) was different as the attendant's job was simply to serve customers rather than to protect them.

Our fourth point is that the High Court's approach must surely apply only to cases involving intentional wrongdoing. ${ }^{39}$ In what sense, for example, is an employee driver in a position of 'authority, power, trust, control and the ability to achieve intimacy' with respect to a pedestrian whom he negligently runs over? The answer to that question, surely, is none. However, this limitation on the circumstances in which the High Court's decision applies is of limited significance. That is because the second stage of the test for vicarious liability arises most acutely in cases involving intentional wrongdoing.

Our fifth point concerns the reason for the difference in approach as between Australia and the UK. It is likely that a key influence in this regard was the civil liability legislation that was enacted in Australia at the start of the twenty-first century. ${ }^{40}$ At that time, statutes were passed in all Australian jurisdictions in response to an 'insurance crisis' ${ }^{41}$ The legislation both significantly circumscribed the circumstances in which liability arises in tort and severely limited the quantum of recovery. Even though the civil liability statutes say little about vicarious liability, ${ }^{42}$ the legislation conveys a clear message that an expansive law of torts is politically unacceptable. This restrictive climate accounts, at least in part, for the different approaches to vicarious liability that have been taken in Australia and the UK. It is

\footnotetext{
39 Perhaps this is what was meant by 'cases of this kind': Prince Alfred College (n 4) [80]-[81].

40 eg Civil Liability Act 2002 (NSW).

41 For discussion see JJ Spigelman, 'Negligence: The Last Outpost of the Welfare State' (2002) 76 Australian Law Journal 432; Peter Cane, 'Reforming Tort Law in Australia: A Personal Perspective' (2003) 27 Melbourne University Law Review 649; Harold Luntz, 'The Australian Picture' (2004) 35 Victoria University of Wellington Law Review 879.

42 A handful of provisions in the statutes concerns vicarious liability, eg Civil Liability Act 2002 (NSW), ss $3,5 \mathrm{Q}, 26 \mathrm{X}$.
} 
true, of course, that the legislature has intervened repeatedly in recent years in tort law in the UK, usually to restrict the circumstances in which liability arises. ${ }^{43}$ However, the UK legislation is categorically different from that which was enacted in Australia. Put simply, the UK statutes are far more modest in terms of the changes made.

Our sixth point relates to the fact that there is no serious discussion of the justifications for vicarious liability in Prince Alfred College. The only comment made in this regard was that the requirement that the wrongful act occur in the course of employment can provide an 'objective, rational basis for liability and for its parameters' ${ }^{44}$ However, the requirement that any wrongdoing occur in the course of employment, though clearly a limit on the scope of vicarious liability, fails to offer a 'rational basis' for the doctrine. It simply raises the question why should a faultless employer be liable for wrongs committed by an employee in the course of their employment? This omission is unfortunate as understanding why such a rule exists is, in our opinion, crucial to determining the circumstances in which it should apply.

The High Court was apparently deterred from considering the reasons for the institution of vicarious liability on account of the fact that a 'fully satisfactory rationale for the imposition of vicarious liability' has been 'slow to appear in the case law'. ${ }^{45}$ It is certainly true that the search for a comprehensive justification of the law in this regard has so far been unsuccessful. The various justifications for the doctrine that have been offered in the authorities have rightly been criticised for their lack of explanatory power. ${ }^{46}$ For example, the argument that employers ought to pay for their employees' torts because employers are more likely to have "deep pockets ${ }^{47}$ does not explain why neither impecuniosity on the part of the employer nor capacity to pay on the part of the employee is not a defence to vicarious liability. It is also incapable of accounting for why liability is not imposed in all cases on the deepest pocket of all: the state. Similarly, the suggestion that vicarious liability encourages

43 eg Compensation Act 2006; Defamation Act 2013; Enterprise and Regulatory Reform Act 2013, s 69; Social Action, Responsibility and Heroism Act 2015.

$44 \quad$ Prince Alfred College (n 4) [40].

45 ibid [39] quoting Hollis v Vabu Pty Ltd [2001] HCA 44 [35].

46 See eg Paula Giliker, Vicarious Liability in Tort: A Comparative Perspective (Cambridge University Press 2010) ch 8; Robert Stevens, Torts and Rights (Oxford University Press 2007) 258-59; Phillip Morgan, 'Vicarious Liability on the Move' (2013) 129 Law Quarterly Review 139, 142.

47 See eg Limpus v London General Omnibus Co (1862) 1 H\&C 526, 539; 158 ER 993, 998; Various Claimants (n 2) [35]. 
higher standards of safety ${ }^{48}$ ignores (among other things) the fact that the consequence of an inability to prove fault on the part of the vicariously liable defendant is that the taking additional safety measures is deemed to be unreasonable. ${ }^{49}$ And the enterprise liability justification for vicarious liability, which is currently fashionable in the $\mathrm{UK},{ }^{50}$ fails to explain why the wrongdoer needs to be an employee (as opposed to an independent contractor) of the defendant. ${ }^{51}$ Neither does it explain why the harm must have been negligently caused by the employee as the defendant potentially has benefited from the creation of the risk regardless of whether there is negligence. It also raises the question as to why the mere creation of a risk that materialises justifies the imposition of vicarious liability when liability in tort usually arises only for the materialisation of wrongly created risks.

Even combined, the reasons on offer in support of the vicarious liability doctrine take us no further: multiple unconvincing reasons do not become a convincing reason when combined. None of this is to say, of course, that no satisfactory justification for vicarious liability exists. Rather, the point is that such a justification has yet to be identified. However, as unsatisfactory as this position is, the vicarious liability doctrine is now so well-established in the law that the main options available in these circumstances for the development of the law, being to abolish the doctrine entirely ${ }^{52}$ or undertake radical reform to make it sit more comfortably with the proffered justifications, are likely to be politically unacceptable.

The difficulty of justifying the vicarious liability doctrine as it presently exists has prompted some authors to argue the law of vicarious liability might have been fundamentally misunderstood and that what appears to be liability that is vicarious is in fact liability arising directly. ${ }^{53}$ According to traditional learning, vicarious liability entails duplicating the

Bazley v Curry [1999] 2 SCR 534 [32] (McLachlin J).

Donal Nolan, 'Enterprise Liability and the Common Law by Douglas Brodie' (2012) 41 Industrial Law Journal 370, 372.

eg Mohamud (n 5) [40].

For more on the limitations of the enterprise liability justification for vicarious liability, see James Plunkett ‘Taking Stock of Vicarious Liability’ (2016) 132 Law Quarterly Review 556.

52 As noted in WE Peel and J Goudkamp, Winfield and Jolowicz on Tort (19th edn, Sweet \& Maxwell 2014) para 21.006: '[I]t is inconceivable that a serious proposal for the abolition of vicarious liability will be made so long as the law of torts as we know it remains alive.'

Glanville Williams, 'Vicarious Liability: Tort of the Master or Servant?' (1956) 72 Law Quarterly Review 522; Stevens (n 46) 259-67. 
tortfeasor's liability on the defendant. The defendant is not (unless he is also at fault personally) a wrongdoer. Contrary to this conventional way of understanding things, the rival analysis perceives the law as instead attributing the tortfeasor's acts to the defendant with the result that the defendant is a wrongdoer. The rival approach explains various features of the law. For example, it accounts for why vicarious liability arises only if the claimant is injured by an employee who is at fault. However, the rival analysis simply pushes things back one step, for proponents of the rival understanding need to explain why the tortfeasor's acts ought to be attributed to the defendant. In other words, the rival analysis merely shifts the problem elsewhere.

\section{Conclusion}

The law of vicarious liability is one of the most dynamic and controversial parts of tort law. Perhaps more than any other aspect, it has undergone the greatest amount of development in the UK in response to social changes, such as the increasing specialisation of certain sectors of the workforce and the growing tendency of companies to outsource work. Some of the choices that the UK courts have made with respect to vicarious liability cannot easily be reversed. It remains to be seen whether, as with the Fairchild principle, ${ }^{54}$ the expansionist course that has been charted will come to be regretted. Certainly, it is odd given the lack of a clear justification for the vicarious liability doctrine that its scope has been relentlessly enlarged. As we have intimated above, the main options for the development of the law in these circumstances should be either to abolish the rule completely or to trim it back to the extent that it is supported by the rationales that are on offer.

\section{Author notes}

James Goudkamp is an associate professor of law and fellow of Keble College at the University of Oxford and a barrister at 7 King's Bench Walk.

54 Fairchild v Glenhaven Funeral Services Ltd [2002] UKHL 22. Lord Hoffmann, one of the architects of the Fairchild rule, has doubted whether the House of Lords was right to react to the 'hard case' with which it was presented in Fairchild in the way that it did. His Lordship suggested that, had he and the other Law Lords foreseen that Parliament would be willing to tackle the problem with which they were faced, the House would have left the legislature to grapple with it. See Lord Hoffmann, 'Fairchild and After' in Andrew Burrows, David Johnston QC and Reinhard Zimmermann (eds), Judge and Jurist: Essays in Memory of Lord Rodger of Earlsferry (Oxford University Press 2013); 'Constitutionalism and Private Law' (Cambridge Freshfields Annual Law Lecture, 28 January 2015). 
James Plunkett is a barrister of the Victorian bar.

\section{Acknowledgments}

The authors would like to thank the anonymous referee for his or her useful comments on a draft of this note. 